\title{
Tuberculosis among the homeless: should we change the strategy?
}

\author{
M. Dias, ${ }^{*}$ R. Gaio, ${ }^{\ddagger \neq}$ P. Sousa, ${ }^{\S}$ M. Abranches,,$^{\S}$ M. Gomes, ${ }^{\text {"\# }}$ O. Oliveira, ${ }^{\pi}$ M. Correia-Neves, ${ }^{* * t \dagger}$ \\ E. Ferreira, ${ }^{\neq \pm}$R. Duarte* ${ }^{*}$
}

*Pulmonology Department, Centro Hospitalar de Vila Nova de Gaia/Espinho, Vila Nova de Gaia, ${ }^{\dagger}$ Department of Mathematics, Faculty of Sciences, and ${ }^{\ddagger}$ Centre of Mathematics, University of Porto, Porto, §Department of Clinical Epidemiology, Predictive Medicine and Public Health, University of Porto Medical School, Porto, "EPIUnit, Institute of Public Health, University of Porto, Porto, \#Occupational Health, Centro Hospitalar de Vila Nova de Gaia/ Espinho, Vila Nova de Gaia, **Life and Health Sciences Research Institute (ICVS), School of Health Sciences, University of Minho, Braga, ${ }^{+\dagger}$ ICVS/3B's, Portugal Government Associate Laboratory, Braga/Guimarães, ${ }^{\ddagger \pm}$ Public Health Department, Agrupamento de Centros de Saúde do Porto Oriental, Porto, Portugal

S U M M AR Y

BACKGROUND: Tuberculosis (TB) is a major concern among high-risk populations such as the homeless. OBJECTIVES: To evaluate TB incidence and treatment outcomes among homeless patients in Portugal and to identify predictors of unsuccessful TB treatment outcomes among the homeless.

DESIGN: This was a retrospective cohort study of all TB patients notified in Portugal from 2008 to 2014. Characteristics of homeless TB patients were assessed and predictors of unsuccessful TB treatment were determined using logistic regression.

RESULTS: TB incidence among the homeless was 122/ 100000 homeless persons and was positively correlated with TB incidence among non-homeless persons. Homeless TB patients had a higher prevalence of alcohol and/or drug use, human immunodeficiency virus (HIV) co-infection, cavitary TB and smear positivity. The rate of unsuccessful treatment outcomes among the homeless was $28.6 \%$, and was significantly associated with increased age, injection drug use (IDU) and HIV coinfection.

CONCLUSION: TB incidence among homeless persons was five times that among the non-homeless, and higher in regions with greater $\mathrm{TB}$ incidence among nonhomeless persons. The successful treatment outcome rate was lower. Predictors of unsuccessful treatment were age, IDU and HIV co-infection. Integrated TB programmes targeting homeless and non-homeless patients, with measures targeting specific characteristics, may contribute to TB elimination in Portugal.

KEY WORDS: homelessness; predictors; treatment success
TUBERCULOSIS (TB) remains one of the leading causes of death due to an infectious agent worldwide. ${ }^{1}$ Although TB incidence has decreased in industrialised countries, it remains a major cause of disease among high-risk populations such as the homeless. ${ }^{2,3}$ The definition of homelessness varies from country to country. In 2009, at the United Nations Economic Commission for Europe Conference of European Statisticians, a homeless person was defined as a person living in the streets without a shelter or a person with no place of usual residence, who moves frequently between various types of accommodation. ${ }^{4}$

Although the association between TB and homelessness was recognised at the beginning of the twentieth century, ${ }^{5}$ there are few worldwide studies on the subject. Data evaluating TB incidence and the socio-economic factors associated with $\mathrm{TB}$ in this group are hard to obtain, as reports on the total number of homeless persons and their characteristics are scarce. Some studies have reported a lower treatment success rate among homeless TB patients; however, the predictive factors for unsuccessful treatment outcomes have not been well studied. ${ }^{2,3,6,7}$

The aims of the present study were to evaluate the TB incidence rate and assess treatment outcomes among the homeless in Portugal, and to identify predictors for unsuccessful treatment.

\section{STUDY POPULATION AND METHODS}

\section{Study design and data collection}

This was a retrospective cohort study conducted in Portugal. The data source was the latest Census (2011) provided by the National Statistical System $(\mathrm{INE})^{8}$ and the National TB Surveillance System

Correspondence to: Margarida Dias, Pulmonology Department, Centro Hospitalar Vila Nova de Gaia/Espinho, Rua Conceição Fernandes, S/N, 4434-502 Vila Nova de Gaia, Portugal. e-mail: margarida.pinho.dias@chvng.min-saude.pt Article submitted 5 August 2016. Final version accepted 7 November 2016. 
(SVIG). In Portugal, the notification of all reported TB cases to the SVIG is mandatory; a standard form covering, among other items, the patient's demographic data, geographic localisation, housing status, human immunodeficiency virus (HIV) status, substance use, drug susceptibility testing results and treatment outcome is used.

We calculated the national TB incidence among homeless and non-homeless persons for 2011. The association between TB incidence among homeless persons and national indicators by territorial unit was analysed using an ecological study design. Portugal is divided into 18 districts and two autonomous regions, and this was the territorial unit selected. The national indicators obtained from the 2011 Census were population density, number of homeless persons, prevalence of migrants, number of physicians per inhabitant and unemployment rate. We selected all TB cases reported to the SVIG during 2008-2014 for the study analysis. We first compared treatment outcomes by housing status (homeless vs. non-homeless), and then identified predictors of unsuccessful treatment in the homeless subgroup.

Ethical approval for the study was not required, as only encrypted information was used.

\section{Definitions}

A person was considered homeless if he/she did not have a regular and adequate residence or lived in a temporary residence provided by a social institution. TB treatment outcomes were described as successful or unsuccessful. Successful treatment outcomes included treatment completion and cure; unsuccessful treatment outcomes included treatment failure, loss to follow-up, transferred out or died, based on World Health Organization definitions. ${ }^{1}$

\section{Statistical analysis}

For district-wise data, the strength of the (monotone) association between the national indicators selected and $\mathrm{TB}$ incidence among homeless persons was evaluated using the Spearman's rank correlation coefficient. Descriptive statistics of the variables of interest were expressed as absolute and relative frequencies or means \pm standard deviation. $\chi^{2}$ and $t$-tests were used to evaluate the statistical significance of the independence between each risk factor and the response. Logistic regression models were used to identify risk factors for unsuccessful TB treatment outcomes among homeless patients.

The choice of the best model was based on the (lowest) Akaike Information Criterion. The probability threshold leading to the maximum value of the sum between sensitivity and specificity was computed, which should define the cut-off for class membership if predictions are to be made. All statistical analyses were performed using $R$ software environment for statistical computation and graphics,
Table 1 Spearman's correlation between national indicators and TB incidence among homeless persons, Portugal, 2011

\begin{tabular}{lcr}
\hline National indicators & $\begin{array}{c}\text { Correlation } \\
\text { coefficient }\end{array}$ & $P$ value \\
\hline TB incidence in the general population & 0.795 & $<0.001$ \\
Number of homeless persons & 0.539 & 0.014 \\
Population density & 0.379 & 0.100 \\
Number of physicians/inhabitants & 0.328 & 0.157 \\
Prevalence of immigrants & 0.303 & 0.195 \\
Unemployment rate & 0.092 & 0.716 \\
\hline
\end{tabular}

$\mathrm{TB}=$ tuberculosis

version 3.3.0 (R Computing, Vienna, Austria). ${ }^{9}$ The significance level was set at 0.05 .

\section{RESULTS}

\section{TB incidence rate among homeless persons}

The 2011 Census identified 92053 homeless persons among a total population of 10562178 in Portugal. In the same year, $2609 \mathrm{~TB}$ cases were notified, 112 $(4 \%)$ of whom were homeless. The TB incidence rate among homeless persons was therefore 122 per 100000 homeless persons, while among non-homeless persons this was 23/100 000 population.

Table 1 shows the results of the association between TB incidence among homeless persons and the national indicators evaluated. As mentioned earlier, calculations were based on dividing Portugal into 20 territorial units. Of the indicators evaluated, $\mathrm{TB}$ incidence among the non-homeless had the strongest positive correlation with TB incidence among the homeless (Table 1).

TB outcomes, 2008-2014

Between 2008 and 2014, 18380 cases of TB disease were reported to the SVIG. We excluded 725 patients due to unknown housing status. Of the 17655 patients included, $734(4 \%)$ were homeless. Table 2 shows the univariate analyses of patient characteristics by housing status. Most homeless TB patients were male $(77.7 \%)$ and were aged between 25 and 64 years $(76.8 \%)$. The prevalence of alcohol abuse was three times higher $(33.3 \%$ vs. $12.8 \%)$ and drug use almost five times higher $(41.3 \%$ vs. $8.4 \%)$ among homeless persons than among the non-homeless. There was also a higher prevalence of immigrants ( $21.1 \%$ vs. $15.3 \%)$, previous TB diagnosis $(12.7 \%$ vs. $8.8 \%)$ and HIV co-infection $(32.6 \%$ vs. $10.1 \%)$ among the homeless. With regard to the clinical characteristics analysed, the prevalence of positive acid-fast bacilli (AFB) in respiratory specimens and cavitary lung disease was significantly higher in homeless patients $(70.7 \%$ vs. $65.8 \%$ and $44.6 \%$ vs. $39.0 \%$, respectively). Extra-pulmonary disease was more frequent in non-homeless patients $(32.3 \%$ vs. $27.2 \%)$. There were no differences between homeless and non-homeless persons regarding susceptibility of 
Table 2 Characteristics of homeless and non-homeless persons with TB disease

\begin{tabular}{|c|c|c|c|}
\hline & $\begin{array}{l}\text { Homeless persons } \\
(n=734) \\
n(\%)\end{array}$ & $\begin{array}{l}\text { Non-homeless persons } \\
(n=16921) \\
n(\%)\end{array}$ & $P$ value \\
\hline $\begin{array}{l}\text { Male sex } \\
\text { Age, years, mean } \pm S D\end{array}$ & $\begin{array}{c}570(77.7) \\
48.1 \pm 18.4\end{array}$ & $\begin{array}{l}10941(64.7) \\
46.8 \pm 18.9\end{array}$ & $\begin{array}{r}<0.001 \\
0.045\end{array}$ \\
\hline $\begin{array}{l}\text { Substance use } \\
\text { Alcohol use } \\
\text { Drug use }\end{array}$ & $\begin{array}{l}222(33.3) \\
280(41.3)\end{array}$ & $\begin{array}{l}1987(12.0) \\
1391(8.4)\end{array}$ & $\begin{array}{l}<0.001 \\
<0.001\end{array}$ \\
\hline $\begin{array}{l}\text { Immigrant } \\
\text { Previous TB }\end{array}$ & $\begin{array}{r}155(21.1) \\
93(12.7)\end{array}$ & $\begin{array}{l}2591(15.3) \\
1484(8.8)\end{array}$ & $\begin{array}{l}<0.001 \\
<0.001\end{array}$ \\
\hline $\begin{array}{l}\text { Clinical characteristics } \\
\text { AFB smear-positive respiratory specimens } \\
\text { Cavitary lung disease } \\
\text { Extra-pulmonary disease } \\
\text { HIV-positive result } \\
\text { Isoniazid resistance } \\
\text { Rifampicin resistance } \\
\text { MDR-TB }\end{array}$ & $\begin{array}{c}395(70.7) \\
300(44.6) \\
198(27.2) \\
239(32.6) \\
30(6.8) \\
13(2.9) \\
11(2.5)\end{array}$ & $\begin{array}{c}7550(65.8) \\
6154(39.0) \\
5261(32.3) \\
1717(10.1) \\
684(7.2) \\
175(1.8) \\
159(1.7)\end{array}$ & $\begin{array}{r}0.018 \\
0.003 \\
0.003 \\
<0.001 \\
0.260 \\
0.171 \\
0.201\end{array}$ \\
\hline $\begin{array}{l}\text { TB treatment outcome } \\
\text { Successful } \\
\text { Unsuccessful } \\
\text { Not reported }\end{array}$ & $\begin{array}{r}443(60.4) \\
210(28.6) \\
81(11.0)\end{array}$ & $\begin{array}{rl}13 & 743(81.3) \\
1 & 681(9.9) \\
1 & 497(8.8)\end{array}$ & $<0.001$ \\
\hline
\end{tabular}

$\mathrm{TB}=$ tuberculosis; $\mathrm{SD}=$ standard deviation; $\mathrm{AFB}=$ acid-fast bacilli; HIV= human immunodeficiency virus; MDR-TB = multidrug-resistant TB.

Mycobacterium tuberculosis to isoniazid (INH) and/ or rifampicin (RMP).

Overall, the prevalence of unsuccessful treatment outcomes was higher in homeless patients than in non-homeless patients $(28.6 \%$ vs. $9.9 \%)$. The rate of treatment failure was similar $(0 \%$ vs. $<0.1 \%)$; however, homeless persons had a higher mortality rate $(14.4 \%$ vs. $5.4 \%)$, a higher number of cases lost to follow-up $(9.4 \%$ vs. $3 \%)$ and a higher number of patients transferred out $(4.7 \%$ vs. $1.5 \%)$.

\section{Predictors of unsuccessful TB treatment outcomes in} homeless persons, 2008-2014

Of the 734 homeless patients, TB treatment outcomes were reported for 653. The univariate analysis of characteristics associated with unsuccessful treatment is shown in Table 3. The final model identified age, injection drug use (IDU) and HIV co-infection to be positively associated with unsuccessful treatment in this group (Table 4). For each 1-year increase in age, the odds of unsuccessful treatment increased by $3 \%$. For example, a 10-year increase in age would lead to $30 \%$ higher odds of unsuccessful treatment. Individuals with HIV co-infection had 2.1 times higher odds of having unsuccessful treatment than non-HIVinfected patients. The odds of unsuccessful treatment among injection drug users were twice as high as those of non-users. No significant interactions between these variables were identified. The area under the receiver operating characteristic curve (AUC) for this model to estimate an unsuccessful treatment outcome was $0.676(95 \%$ confidence

Table 3 Characteristics of homeless TB patients by treatment outcome

\begin{tabular}{lcrr}
\hline & $\begin{array}{c}\text { Unsuccessful treatment } \\
(n=210) \\
n(\%)\end{array}$ & $\begin{array}{c}\text { Successful treatment } \\
(n=443) \\
n(\%)\end{array}$ & $P$ value \\
\hline Male sex & $161(76.7)$ & $343(77.4)$ & 0.829 \\
Age, years, mean \pm SD & $52.5 \pm 19.7$ & $46.2 \pm 17.7$ & $<0.001$ \\
Substance use & & & \\
$\quad$ Alcohol abuse & $59(33.1)$ & $133(32.3)$ & 0.837 \\
Non-injection drug use & $67(36.2)$ & $129(31.5)$ & 0.254 \\
Injection drug use & $85(44.7)$ & $124(30.1)$ & $<0.001$ \\
Immigrant & $42(20.0)$ & $96(21.7)$ & 0.625 \\
Previous TB & $32(15.2)$ & $51(11.5)$ & 0.182 \\
Clinical characteristics & & & \\
AFB smear-positive respiratory specimens & $111(71.2)$ & $237(68.9)$ & 0.611 \\
Cavitary lung disease & $80(43.5)$ & $181(43.7)$ & 0.956 \\
Extra-pulmonary disease & $55(26.2)$ & $123(28.1)$ & 0.614 \\
HIV co-infection & $87(41.4)$ & $126(28.4)$ & 0.001 \\
Isoniazid resistance & $10(7.9)$ & $5(5.4)$ & 0.718 \\
Rifampicin resistance & $5(4)$ & $4(1.3)$ & 0.157 \\
MDR-TB & $4(3.2)$ & 0.207 \\
\hline
\end{tabular}

$\mathrm{TB}=$ tuberculosis; $\mathrm{SD}=$ standard deviation; $\mathrm{AFB}=$ acid-fast bacilli; HIV= human immunodeficiency virus; MDR-TB = multidrug-resistant TB . 
Table 4 Multiple logistic regression to identify factors associated with unsuccessful treatment among homeless tuberculosis patients

\begin{tabular}{lccrr}
\hline Variables & Coefficients & SE & $P$ value & OR (95\%Cl) \\
\hline Intercept & 2.920 & 0.371 & $<0.001$ & - \\
Age & 0.032 & 0.006 & $<0.001$ & $1.033(1.021-1.045)$ \\
Injection drug use & 0.721 & 0.256 & 0.002 & $2.056(1.247-3.403)$ \\
HIV co-infection & 0.759 & 0.249 & 0.005 & $2.135(1.312-3.494)$ \\
\hline
\end{tabular}

$\mathrm{TB}=$ tuberculosis; $\mathrm{SE}=$ standard error; $\mathrm{OR}=$ odds ratio; $\mathrm{CI}=$ confidence interval; HIV = human immunodeficiency virus.

interval $0.631-0.721)$. The probability threshold maximising the sum of sensitivity with specificity was estimated at 0.617 , leading to individual sensitivity and specificity values of respectively 0.706 and 0.577 .

\section{DISCUSSION}

TB incidence among homeless persons was approximately five times higher than among the nonhomeless. In Portugal, TB incidence in 2003 among the homeless (122/100 000 homeless) was higher than the incidence reported in the United States (36-47) 100000 homeless), but lower than that in London, UK (788/100 000 homeless). ${ }^{2,3}$

Those regions in Portugal with higher TB incidence among the homeless also recorded higher TB incidence in the non-homeless population. Furthermore, the majority of TB patients were non-homeless persons $(96 \%)$. We therefore hypothesise that better TB control in the non-homeless population would reduce TB among homeless persons. We do, however, recognise that as this hypothesis is based on an ecological study design, our findings for the groups may not apply to individuals in each group. Our study identified distinct clinical characteristics of homeless TB patients, which requires an approach specific to this population that could contribute to the development of a more comprehensive TB control programme.

The prevalence of alcohol and/or drug use, conditions associated with a higher risk of TB disease and poor treatment adherence, was higher among homeless TB patients. ${ }^{10}$ It is therefore important to take measures to treat drug addiction in homeless $\mathrm{TB}$ patients. Almost one third of homeless TB patients presented with HIV co-infection. HIV infection is a major risk factor for latent tuberculous infection (LTBI) and TB disease, and the presence of TB-HIV co-infection is often associated with drug interactions, overlapping toxicity profiles and higher mortality. ${ }^{11}$ The large number of homeless persons with TB-HIV co-infection highlights the need for a structured screening programme for LTBI and active TB in homeless patients, particularly in the case of HIVpositive patients. According to a computer simulation model created by Brewer et al., a 10\% increase in accessing treatment for LTBI by HIV-infected homeless persons was associated with an $8.9-10.9 \%$ decline in projected TB cases over 10 years. ${ }^{12}$

Furthermore, $71.2 \%$ of homeless persons were AFB smear-positive and $44.6 \%$ presented with cavitary TB disease. We had no means of determining the extent to which homeless persons experienced diagnostic delays, but these data suggest that homeless patients generally present with a more advanced and infectious form of disease at the time of diagnosis. A possible explanation may be the barriers faced by homeless persons to medical care, as reported in other studies. ${ }^{13,14}$ Lack of health insurance is a problem for most homeless people in several countries, including the United States. ${ }^{13}$ Although Portugal has a universal health care system, the homeless are likely to prioritise subsistence needs such as food and shelter, which may delay their access to health care services, as described in previous studies. ${ }^{14}$ By fulfilling the basic needs of the homeless, providing them with easy access to medical care and facilitating anti-tuberculosis treatment for this group, we can increase their chances of treatment success. As mentioned above, there was a high prevalence of alcohol and drug consumption among the homeless. As persons with addictions are more likely to procrastinate and refuse medical care, ${ }^{15}$ delays in seeking medical care increase the risk of community transmission, especially if homeless persons live in overcrowded social residences with poorly ventilated rooms. ${ }^{16} \mathrm{~TB}$ treatment guidelines recommend longer treatment for patients with cavitary TB disease, ${ }^{17}$ which can be difficult to achieve in homeless people without additional support.

It may seem surprising that, in our study, the prevalence of INH and/or RMP resistance was not statistically higher in homeless subjects, despite a higher prevalence of previous history of TB. In Portugal, directly observed treatment is mandatory, and for homeless TB patients, there are partnerships with organisations that help ensure that homeless persons, drug users and HIV-co-infected patients receive treatment. ${ }^{18}$ This is likely to improve treatment adherence and thereby reduce the acquisition of drug resistance. In our study, most negative outcomes among homeless persons were death, rather than loss to follow-up. Nevertheless, $9.4 \%$ of the homeless were lost to follow-up and $4.7 \%$ were transferred out, indicating that $\mathrm{TB}$ is still not effectively controlled in this group. 
Despite all efforts by governmental agencies and non-governmental organisations worldwide, previous studies have also reported poorer outcomes among homeless people. ${ }^{2,3,19}$ However, predictors of unsuccessful treatment outcomes among the homeless are not well documented in the literature.

Our study identified age, IDU and HIV co-infection to be significantly associated with unsuccessful treatment outcome. These factors are also known predictors for poor outcomes in non-homeless persons. ${ }^{20,21}$ The inverse relationship between age and TB treatment success has been previously reported in the literature and can be explained by general physiological deterioration with age. ${ }^{20,22}$ It is also well known that homeless persons die prematurely, mainly due to infectious diseases. ${ }^{23}$ Previous studies have also shown an association between IDU and poor TB outcomes, mainly due to poor adherence. ${ }^{10}$ However, other study findings suggest that adherence among drug users is improved when DOT is provided with methadone or combined with monetary incentives, which can be useful in this population. ${ }^{24}$ Several studies have also reported that HIV coinfection is associated with higher mortality and unsatisfactory outcomes among TB patients. ${ }^{11,25}$ It is not known whether HIV patients in our study received highly active antiretroviral therapy (HAART), but it is known that patients who received HAART during anti-tuberculosis treatment had better outcomes and more rapid sputum conversion. ${ }^{25}$ It is therefore particularly important to ensure adherence to HAART and anti-tuberculosis treatment among the homeless to improve treatment outcome and reduce the risk of $\mathrm{TB}$ transmission. The final regression model exhibited an AUC estimated at 0.676 , reflecting a relatively low discrimination ability. Previous studies identified mental illness and malnutrition as factors associated with unsuccessful treatment outcomes; other factors may also be implicated. ${ }^{26}$

We recognise the limitations in our study: first, $\mathrm{TB}$ incidence among the homeless was only calculated for 2011 as this is the most recent year with official statistics on the number of homeless people in Portugal. Second, estimating TB incidence among the homeless could be problematic, as the total number of homeless persons may be underreported and TB in this group may have been underdiagnosed. To mitigate this limitation, we included reliable data from the National Census and SVIG. However, an ascertainment bias cannot be excluded, as the study is based on notification data. Although TB notification is mandatory in Portugal, there is no guarantee that diagnostic capacity and proactive case-finding efforts were similar in all regions. Finally, we only evaluated TB disease and not LTBI, although LTBI control may also reduce $\mathrm{TB}$ in homeless persons.

The major strengths of our study were its nation- wide scope, the inclusion of all reported TB cases, the analysis of multiple risk factors and adequate control of confounding variables.

Further prospective studies are needed to determine other predictors of unsuccessful treatment to optimise TB control in this vulnerable population.

\section{CONCLUSIONS}

TB disease is highly prevalent among homeless persons, and is higher in regions with greater TB incidence in non-homeless patients. Homeless TB patients had a higher prevalence of alcohol/drug use, previous TB, HIV co-infection, smear positivity and cavitary TB disease than non-homeless patients. The rate of unsuccessful TB treatment outcomes is also higher in this population, mainly due to higher mortality. Age, IDU and HIV co-infection are significantly associated with unsuccessful treatment outcomes. To achieve the national goal of TB elimination, we need to develop measures that specifically target homeless persons.

\section{Acknowledgements}

The authors thank the following researchers of the Study Group for Infectious Diseases of Instituto de Saúde Pública da Universidade do Porto who collaborated on this project: B Miranda, C Carvalho, C Matos, C Carvalho, G Rodrigues, J Gonçalves, L Maio and T Rito.

This work was supported by contributions from Iceland, Liechtenstein and Norway through the European Economic Area Grants under the Public Health Initiatives Programme (PT 06, grant number 138DT1). RG was also partially supported by Centro de Matemática da Universidade do Porto (UID/MAT/00144/2013), which is funded by Fundação do Ministério de Ciência e Tecnologia (Portugal) with national (MEC) and European structural funds (Fonds européen de développement économique et régional) under the PT2020 Partnership Agreement.

Conflicts of interest: none declared.

\section{References}

1 World Health Organization. Global tuberculosis report, 2015. WHO/HTM/TB/2015.22. Geneva, Switzerland: WHO, 2015.

2 Story A, Murad S, Roberts W, Verheyen M, Hayward A C. Tuberculosis in London: the importance of homelessness, problem drug use and prison. Thorax 2007; 62: 667-671.

3 Bamrah S, Yelk Woodruff R S, Powell K, Ghosh S, Kammerer J S, Haddad M B. Tuberculosis among the homeless, United States, 1994-2010. Int J Tuberc Lung Dis 2013; 17: 1414-1419.

4 Economic Commission For Europe. Counting homeless people in the 2010 census round: use of enumeration and register-based methods. ECE/CES/GE.41/2009/7. Geneva, Switzerland: ECE, 2009.

5 Knopf S A. Tuberculosis as a cause and result of poverty. JAMA 1914; 63: 1720-1725.

6 LoBue P A, Cass R, Lobo D, Moser K, Catanzaro A. Development of housing programs to aid in the treatment of tuberculosis in homeless individuals: a pilot study. Chest 1999; 115: 218-223.

7 Ranzani O T, Carvalho C R, Waldman E A, Rodrigues L C. The impact of being homeless on the unsuccessful outcome of treatment of pulmonary TB in São Paulo State, Brazil. BMC Med 2016; 14: 41. 
8 Instituto Nacional de Estatística. Censos 2011 resultados definitivos: Portugal. Lisbon, Portugal: INE, 2012. [Portuguese]

9 Development CoreTeam. R: a language and environment for statistical computing. Vienna, Austria: $\mathrm{R}$ Foundation for Statistical Computing, 2008.

10 Deiss R G, Rodwell T C, Garfein R S. Tuberculosis and illicit drug use: review and update. Clin Infect Dis 2009; 48: 72-82.

11 Pimpin L, Drumright L N, Kruijshaar M E, et al. Tuberculosis and HIV co-infection in European Union and European Economic Area countries. Eur Respir J 2011; 38: 1382-1392.

12 Brewer T, Heymann S J, Krumplitsch S, Wilson M, Colditz G, Fineberg H. Strategies to decrease tuberculosis in US homeless populations: a computer simulation model. JAMA 2001; 286: 834-842.

13 Tankimovich M. Barriers to and interventions for improved tuberculosis detection and treatment among homeless and immigrant populations: a literature review. J Community Health Nurs 2013; 30: 83-95.

14 Gelberg L, Gallagher T C, Andersen R M, Koegel P. Competing priorities as a barrier to medical care among homeless adults in Los Angeles. Am J Public Health 1997; 87: 217-220.

15 McCoy C, Metsch L, Chitwood D, Miles C. Drug use and barriers to use of health care services. Subst Use Misuse 2001; 36: 789-804.

16 van Hest N A, Aldridge R W, de Vries G, et al. Tuberculosis control in big cities and urban risk groups in the European Union: a consensus statement. Euro Surveill 2014; 19: 20728.

17 Benator D, Bhattacharya M, Bozeman L, et al. Rifapentine and isoniazid once a week versus rifampicin and isoniazid twice a week for treatment of drug-susceptible pulmonary tuberculosis in HIV-negative patients: a randomized clinical trial. Lancet 2002; 360: 528-534.
18 Duarte R, Santos A, Mota M, Carvalho A, Marques A, Barros $H$. Involving community partners in the management of tuberculosis among drug users. Public Health 2011; 125: 6062.

19 Khan K, Rea E, McDermaid C, et al. Active tuberculosis among homeless persons, Toronto, Ontario, Canada, 1998-2007. Emerg Infect Dis 2011; 17: 357-365.

20 Caylà J A, Caminero J A, Rey R, et al. Current status of treatment completion and fatality among tuberculosis patients in Spain. Int J Tuberc Lung Dis 2004; 8: 458-464.

21 Baussano I, Pivetta E, Vizzini L, Abbona F, Bugiani M. Predicting tuberculosis treatment outcome in a low-incidence area. Int J Tuberc Lung Dis 2008; 12: 1441-1448.

22 Falzon D, Le Strat Y, Belghiti F, Infuso A. EuroTB correspondents exploring the determinants of treatment success for tuberculosis cases in Europe. Int J Tuberc Lung Dis 2005; 9: 1224-1229.

23 Morrison D. Homelessness as an independent risk factor for mortality: results from a retrospective cohort study. Int $\mathrm{J}$ Epidemiol 2009; 38: 877-883.

24 Gourevitch M, Wasserman W, Panero M, Selwyn P. Successful adherence to observed prophylaxis and treatment of tuberculosis among drug users in a methadone program. J Addict Dis 1996; 15: 93-104.

25 Nahid P, Gonzalez L, Rudoy I, et al. Treatment outcomes of patients with HIV and tuberculosis. Am J Respir Crit Care Med 2007; 175: 1199-1206.

26 Waitt C J, Squire S B. A systematic review of risk factors for death in adults during and after tuberculosis treatment. Int $\mathrm{J}$ Tuberc Lung Dis 2011; 15: 871-885. 
CONTEXTE : La tuberculose (TB) est un souci majeur dans les populations à haut risque comme les personnes sans domicile fixe.

OвJECTIFS : Evaluer le taux d'incidence de la TB et les résultats du traitement parmi des patients sans domicile fixe au Portugal et identifier les facteurs de prédiction d'échec du traitement de la TB parmi ces patients.

SCHÉMA : Etude rétrospective de cohorte incluant tous les patients TB notifiés au Portugal entre 2008 et 2014. Les caractéristiques des patients sans domicile fixe ont été évaluées et les facteurs de prédiction d'échec du traitement de la TB ont été déterminés par régression logistique.

RÉSULTATS : Le taux d'incidence de la TB parmi les personnes sans domicile fixe a été de 122/100 000, et il a été positivement corrélé avec l'incidence de la TB parmi le reste de la population. Les patients tuberculeux sans domicile fixe avaient une prévalence plus élevée de consommation d'alcool et/ou de drogues, de co- infection au virus de l'immunodéficience humaine (VIH), de forme caverneuse et de frottis positif. Le taux d'échec du traitement a été de $28,6 \%$; l'échec a été significativement associé à un âge plus avancé, à la consommation de drogues injectables et à la co-infection par le VIH.

CONCLUSION: L'incidence de la TB parmi les personnes sans domicile fixe a été cinq fois plus élevée que celle du reste de la population et plus haute dans les régions où l'incidence dans le reste de la population est également plus élevée. Leur taux d'échec du traitement a été plus faible. Les facteurs de prédiction d'échec du traitement ont été l'âge, la consommation de drogues injectables et la co-infection à VIH. Des programmes de TB intégrés ciblant les patients sans domicile fixe et les autres, avec des mesures spécifiques adaptées à leurs caractéristiques particulières, pourrait contribuer à l'élimination de la TB au Portugal.
MARCO DE REFERENCIA: La tuberculosis (TB) constituye una gran preocupación en las poblaciones muy vulnerables como las personas sin hogar.

OBJETIVOS: Evaluar la tasa de incidencia de TB y los desenlaces terapéuticos en las personas sin domicilio en Portugal y definir los factores pronósticos de fracaso terapéutico en este grupo de la población.

MÉ TODO: Fue este un estudio retrospectivo de cohortes de todos los pacientes con diagnóstico de TB notificados del 2008 al 2014 en Portugal. Mediante un análisis de regresión logística se analizaron las características de los pacientes tuberculosos sin hogar y los factores pronósticos de fracaso terapéutico.

RESULTADOS: La tasa de incidencia de TB en la población sin hogar fue 122 por 100000 personas y exhibió una correlación positiva con la incidencia de TB en las personas con domicilio. Los pacientes con diagnóstico de TB y sin hogar presentaron una prevalencia más alta de consumo de alcohol y/o de
RESUMEN

drogas, de coinfección por el virus de la inmunodeficiencia humana (VIH), de lesiones cavernosas y de resultados positivos de la baciloscopia. La tasa de fracaso terapéutico en esta población fue $28,6 \%$ y se asoció de manera significativa con una mayor edad, el consumo de drogas intravenosas y la coinfección por el VIH.

CONCLUSIÓN: La incidencia de TB en las personas sin hogar fue cinco veces mayor que en las personas con domicilio y fue más alta en las regiones con una mayor incidencia de TB en las personas con domicilio. La tasa de éxito terapéutico en las personas sin hogar fue más baja. Los factores pronósticos de fracaso terapéutico fueron la edad, el consumo de drogas intravenosas y la coinfección por el VIH. La ejecución de programas integrados de atención de la TB dirigidos a las personas sin hogar y con domicilio, que comporten medidas específicas que aborden sus características particulares, podría contribuir a la eliminación de la TB en Portugal. 